\title{
POLITIK HUKUM PENGATURAN NETRALITAS APARATUR SIPIL NEGARA DALAM PEMILIHAN KEPALA DAERAH TAHUN 2018
}

\author{
Harry Setya Nugraha \\ Email: harrysn@unja.ac.id \\ Dimar Simarmata \\ Imentari Siin Sembiring \\ Email: siin.imentari98@gmail.com \\ Universitas Jambi
}

\begin{abstract}
Abstrak
Artikel ini mengkaji tentang hadirnya berbagai pengaturan mengenai Netralitas Aparatur Sipil Negara (ASN) dalam Pemilihan Kepala Dearah (Pilkada) yang kemudian membuat penulis bertanya tentang: apa yang menjadi politik hukum pengaturan tentang netralitas ASN dalam Pilkada dan apa pentingnya netralitas ASN tersebut dalam pelaksanaa Pilkada. Tulisan ini merupakan tulisan hukum yuridis-normatif dengan sumber hukum sekunder yang terdiri dari bahan hukum primer, sekunder dan tersier. Pendekatan yang digunakan adalah pendekatan perundang-undangan (statue apporoach) dengan mengkaji berbagai regulasi atau pengaturan mengenai netralitas ASN dalam Pilkada Serentak khususnya Tahun 2018. Tulisan ini berkesimpulan, pertama: politik hukum dari pengaturan menganai netralitas ASN adalah dalam rangka menjaga integritas, profesionalitas, dan netralitas ASN demi terwujudnya Pilkada yang demokratis. Kedua: pengaturan mengenai netralitas ASN menjadi penting guna mencegah penyalahgunaan wewenang baik oleh ASN maupun oleh calon kepala daerah yang bersangkutan.
\end{abstract}

Kata Kunci: Netralitas, ASN, Pemilihan Kepala Daerah

\begin{abstract}
This article analyzes the presence of various regulations regarding the neutrality of civil servant apparatus in the regional election which makes the author ask about what became the politics of law of regulating of the neutrality of civil servant apparatus in the regional election and what was the importance of neutrality of civil servant apparatus in the regional election. This article is a normative juridicial legal writing with secondary legals sources consisting of primary, secondary, and tertiary legal materials. The approach used by the statue apporoach that analyzes of the regulations of neutrality of civil servant apparatus in regional election especially in 2018.The conclution of this paper are, first: the politics of law of regulations of the neutrality of civil servant apparatus was in order to maintain the integrity, professionalism, and neutrality of civil servant apparatus to created democratic regional elections. Second: the regulations of the neutrality of civil servant apparatus was important to prevented abuse of power by both civil servant apparatus and the regional head candidates concerned.
\end{abstract}

Keywords: Neutrality, civil servant apparatus, regional head election. 


\section{PENDAHULUAN}

Netralitas Aparatur Sipil Negara (ASN) bukanlah hal baru dalam kehidupan demokrasi di Indonesia. Dengan kata lain, persoalan netralitas ASN menjadi isu lama yang senantiasa aktual dalam kehidupan bernegara terutama menjelang pelaksaan pesta demokrasi, seperti halnya pada Pemilihan Kepala Daerah (Pilkada) langsung yang tahun ini (dibaca; tahun 2018) telah dilaksanakan. Aktualnya isu netralitas ASN dalam pelaksanaan Pilkada terjadi karena adanya kekhawatiran publik akan keberpihakan ASN kepada salah satu pasangan calon kepala daerah.

Secara historikal, persoalan mengenai netralitas ASN dalam pesta demokrasi sebenarnya telah terjadi sejak Pemilihan Umum (Pemilu) pertama di tahun 1955. Persoalan netralitas ASN menjadi semakin nyata dan kompleks ketika absennya instrumen hukum yang secara komprehensif mampu mengatasi persoalan tersebut. Hingga akhirnya, hadirlah Undang-Undang Nomor 8 Tahun 1974 tentang Netralitas Kepegawaian
Negara yang notabenenya merupakan undang-undang kepegawaian pertama.

Hari ini, segala hal berkenaan dengan ASN diatur dalam Undang-Undang Nomor 5 Tahun 2014 tentang Aparatur Sipil Negara, termasuk didalamnya persoalan netralitas ASN. Dalam Pasal 2 Undang-Undang tersebut dikatakan bahwa penyelenggaraan kebijakan dan manajemen ASN dilaksanakan dengan berdasarkan asas salah satunya asas netralitas. Asas netralitas dalam undangundang tersebut dimaknai bahwa setiap Pegawai ASN tidak berpihak dari segala bentuk pengaruh manapun dan tidak memihak kepada kepentingan siapapun. ${ }^{1}$

Tidak hanya itu, persoalan netralitas ASN kemudian juga diatur dan ditindaklanjuti dengan berbagai peraturan perundang-undangan lainnya. Peraturan perundang-undangan sebagaimana dimaksud diantaranya Undang-Undang Nomor 10 Tahun 2016 tentang Pemilihan Gubernur Bupati \& Walikota, Peraturan Pemerintah Nomor 53 Tahun 2010 tentang Disiplin Pegawai Negeri Sipil,

\footnotetext{
${ }^{1}$ Lihat Penjelasan Pasal 2 huruf $\mathrm{f}$ Undang-Undang Nomor 5 Tahun 2014 tentang Aparatur Sipil Negara
} 
Peraturan Pemerintah Nomor 42 Tahun 2004 tentang Pembinaan Jiwa Koprs dan Kode Etik Pegawai Negeri Sipil, Surat Edaran Komisi Aparatur Sipil Negara Nomor B.2900/KASN/11/2017 tertanggal 10 November 2017 tentang Pengawasan Netralitas Pegawai Aparatur Sipil Negara pada Pilkada Serentak 2018 serta Surat Edaran Menteri Pendayagunaan Aparatur Sipil Negara dan Reformasi Birokrasi Nomor B/71/M/SM.00.00/2017 tertanggal 27 Desember 2017 tentang Pelaksanaan Netralitas Aparatur Sipil Negara.

\section{PERMASALAHAN}

Berdasarkan hal-hal yang telah diungkapkan dalam latar belakang, maka dibuat rumusan masalah sebagai berikut:

1. Apa sebenarnya politik hukum yang hendak dicapai oleh pembentuk undang-undang dan pemerintah dalam membentuk berbagai regulasi tersebut?

2. Seberapa penting sebenarnya netralitas ASN khususnya dalam pelakanaan Pilkada Serentak Tahun 2018?

\section{METODE PENELITIAN}

Metode Pendekatan yang digunakan dalam tulisan ini adalah yuridis normatif dengan sumber berupa data sekunder yang terdiri dari bahan hukum primer, sekunder dan tersier. Pendekatan yang digunakan adalah pendekatan perundangundangan (statue apporoach) dengan mengkaji berbagai regulasi atau pengaturan mengenai netralitas ASN dalam Pilkada Serentak khususnya Tahun 2018.

\section{KAJIAN PUSTAKA}

Pada bagian ini, penulis akan terlebih dahulu menguraikan tentang landasan berfikir atau tinjauan umum mengenai hal-hal yang menjadi pokok pembahasan dalam tulisan ini, yakni netralitas, aparatur sipil negara dan pemilihan kepala daerah. Pertama mengenai netralitas. Menurut arti kata, netralitas berasal dari kata "netral" yang artinya tidak membantu atau tidak mengikuti satu pihak. Sementara netralitas merupakan satu keadaan dan sikap netral atau tidak memihak dan bebas. ${ }^{2}$ Sehingga seseorang dapat dikatakan netral apabila ia tidak memihak kepada satu, dua atau lebih pihak tertentu baik itu seseorang,

\footnotetext{
2 https://kbbi.web.id/netralitas [diakses pada 16 Oktober 2018]
} 
kelompok atau suatu organisasi. Netral juga dapat diartikan sebagai sikap tidak memihak dan tidak berpihak terhadap salah satu kelompok atau golongan, tidak distriminatif, steril dari kepentingan kelompok dan tidak terpengaruh dari kepentingan politik. ${ }^{3}$

Dalam konteks keilmuan, pencarian makna netralitas akan selalu terkait dengan obyektivitas cara pandang. Berkenaan dengan hal tersebut, kebenaran objektivitas ilmu hanya dapat dinilai ketika unsur-unsur subjektivitas ilmu tersebut tidak mempengaruhinya atau tidak masuk sebagai salah satu unsur dari bangunan teori-teorinya. Disini terlihat jelas bahwa ilmu pengetahuan akan dikatakan objektif apabila ia terlepas dari unsur-unsur lain di luar dirinya, termasuk nilai (value free). Begitu ilmu terbebas dari nilai atau unsur-unsur lainnya, maka ilmu dalam keadaan posisi netral, karena ia tidak memihak kepada sesuatu apapun kecuali pada dirinya sendiri (independen). Objektif artinya bahwa data dapat tersedia untuk penelaahan keilmuan tanpa ada

${ }^{3}$ http://repository.umy.ac.id/bitstream/handle/1234 56789/16915/6.\%20BAB\%20II.pdf?sequence $=6 \&$ isAllowed=y [diakses pada 16 Oktober 2018] hubungannya dengan karakteristik individual dari seorang ilmuwan. ${ }^{4}$ Bebas nilai berarti dikotomi yang tegas antara fakta dan nilai mengharuskan subjek peneliti mengambil jarak dengan semesta dengan bersikap imparsial netral. Berdasarkan analogi terhadap netralitas keilmuan, hakikat akan obyektivitas selalu bermuara pada kondisi netral, maka jelas bahwa substansi netral adalah tidak memihak. Sejatinya, kondisi tidak memihak akan terpenuhi jika berada di luar sistem dan tidak memberikan ruang akan intervensi kepentingan. ${ }^{5}$

Kedua, Aparatur Sipil Negara. Menurut Undang-Undang Nomor 5 Tahun 2014 tentang Aparatur Sipil Negara, disebutkan bahwa Aparatur Sipil Negara yang selanjutnya disingkat ASN adalah profesi bagi pegawai negeri sipil dan pegawai pemerintah dengan perjanjian kerja yang bekerja pada

\footnotetext{
${ }^{4}$ Jujun, S, Suriasumantri, 1999, Tentang Hakekat Ilmu: Sebuah Pengantar Redaksi, dalam Ilmu Dalam Perspektif, Jakarta, Yayasan Obor, hlm 115, dalam Tedi Sudajat dan Agus Mulya Karsona, Menyoal Makna Netralitas Pegawai Negeri Sipil dalam Undang-Undang Nomor 5 Tahun 2014 tentang Aparatur Sipil Negara, Jurnal Media Hukum, Vol.23, No.1, Juni 2016, hlm 92. ${ }^{5}$ ibid
} 
instansi pemerintah. ${ }^{6}$ Pegawai Negeri

Sipil (PNS) dalam undang-undang tersebut dimaknai sebagai warga negara Indonesia yang memenuhi syarat tertentu, diangkat sebagai Pegawai ASN secara tetap oleh pejabat pembina kepegawaian untuk menduduki jabatan pemerintahan. ${ }^{7}$ Dalam perspektif yang lain, PNS menurut Kamus Umum Bahasa Indonesia, adalah orang yang bekerja untuk pemerintah atau negara. Menurut Kranenburg PNS adalah pejabat yang ditunjuk, jadi pengertian tersebut tidak termasuk terhadap mereka yang memangku jabatan mewakili seperti anggota parlemen, presiden dan sebagainnya. ${ }^{8}$ Pengertian PNS menurut Mahfud MD ada dua bagian yaitu: ${ }^{9}$

1. Pengertian Stipulatif adalah pengertian yang diberikan oleh undang-undang tentang ASN sebagaimana yang telah penulis sebutkan sebelumnya; dan

\footnotetext{
${ }^{6}$ Lihat Pasal 1 angka 1 Undang-Undang Nomor 5 Tahun 2014 tentang Aparatur Sipil Negara

${ }^{7}$ Lihat Pasal 1 angka 3 Undang-Undang Nomor 5

Tahun 2014 tentang Aparatur Sipil Negara

${ }^{8}$ Sri Hartini, Hukum Kepegawaian Di Indonesia, Sinar Grafika, Jakarta, 2008, hlm. 31

${ }^{9}$ ibid
}

2. Pengertian ekstensif adalah pengertian yang hanya berlaku pada hal-hal tertentu. Hal-hal tertentu yang dimaksud adalah lebih kepada beberapa golongan yang sebenarnya bukan PNS. Contoh: kentuan Pasal 92 KUHP yang berkaitan dengan status anggota dewan rakyat, anggota dewan daerah dan kepala desa. Menurut Pasal 92 KUHP, dijelaskan bahwa yang termasuk ke dalam PNS adalah orang-orang yang dipilih dalam pemilihan berdasarkan peraturan-peraturan umum dan mereka yang bukan dipilih tetapi diangkat menjadi anggota dewan perwakilan rakyat dan anggora dewan daerah serta kepala desa dan sebagainya. Pengertian PNS menurut KUHP sangatlah luas, namun pengertian tersebut hanya berlaku dalam hal orang-orang yang melakukan kejahatan atau pelanggaran jabatan dan tindak pidana lain yang disebutkan dalam KUHP. Jadi pengertian ini tidak termasuk dalam hukum kepegawaian. 
Dari beberapa pengertian tersebut, dapat diketengahkan bahwa sebenarnya PNS adalah orang-orang yang bekerja di lingkungan instansi pemerintahan sesuai dengan syarat-syarat tertentu yang telah ditetapkan oleh peraturan perundangundangan.

Sementara Pegawai Pemerintah dengan Perjanjian Kerja (PPPK) dimaknai sebagai warga negara Indonesia yang memenuhi syarat tertentu, yang diangkat berdasarkan perjanjian kerja untuk jangka waktu tertentu dalam rangka melaksanakan tugas pemerintahan. ${ }^{10}$ Dari penjelasan tersebut, dapat diketahui bahwa ASN termasuk didalamnya adalah PNS dan PPPK yang bekerja pada instansi pemerintahan. Oleh karena itu, jika kita berbicara mengenai netralitas ASN tentu kita sedang bicara tentang netralitas terhadap kedua profesi tersebut.

Ketiga, Pemilihan Kepala Daerah. Dalam Pasal 1 angka 1 Undang-Undang Republik Indonesia Nomor 1 Tahun 2015 Tentang Penetapan Peraturan Pemerintah Pengganti Undang-Undang Nomor 1

${ }^{10}$ Lihat Pasal 1 angka 4 Undang-Undang Nomor 5 Tahun 2014 tentang Aparatur Sipil Negara
Tahun 2014 Tentang Pemilihan Gubernur, Bupati, Dan Walikota Menjadi Undang-Undang sebagaimana telah diubah dengan Undang-Undang Nomor 10 Tahun 2016 disebutkan bahwa Pemilihan Gubernur, Bupati, dan Walikota yang selanjutnya disebut Pemilihan adalah pelaksanaan kedaulatan rakyat di Provinsi dan Kabupaten/Kota untuk memilih Gubernur, Bupati, dan Walikota secara langsung dan demokratis. Pemilihan tersebut dilaksanakan setiap 5 tahun sekali secara serentak di seluruh wilayah NKRI dan secara demokratis berdasarkan asas langsung, umum, bebas, rahasia, jujur dan adil. $^{11}$

Dari ketiga landasan berfikir atau tinjauan umum mengenai netralitas, ASN dan Pilkada sebagaimana penulis uraikan diatas, dapat ditarik benang merah bahwa yang menjadi ruang lingkup berfikir atas netralitas ASN dalam Pilkada Serentak

\footnotetext{
${ }^{11}$ Lihat Pasal 2 dan 3 Undang-Undang Republik Indonesia Nomor 1 Tahun 2015 Tentang Penetapan Peraturan Pemerintah Pengganti Undang-Undang Nomor 1 Tahun 2014 Tentang Pemilihan Gubernur, Bupati, Dan Walikota Menjadi Undang-Undang sebagaimana telah diubah dengan Undang-Undang Nomor 10 Tahun 2016
} 
2018 adalah sikap tidak memihak dari PNS dan PPPK terhadap kepada satu, dua atau lebih pihak tertentu baik itu seseorang, kelompok atau suatu orgaisasi dalam pelaksanaan pemilihan Gubernur, Bupati dan/atau Walikota.

\section{PEMBAHASAN}

\section{A. Politik Hukum Pengaturan tentang} Netralitas ASN dalam Pilkada

\section{Serentak Tahun 2018}

Berbicara mengenai politik hukum pengaturan tentang netralitas ASN dalam Pilkada serentak Tahun 2018, menarik untuk kita pahami terlebih dahulu apa yang menjadi maksud dari politik hukum itu sendiri. Padmo Wahjono mengatakan bahwa politik hukum adalah kebijakan dasar yang menentukan arah, bentuk, maupun isi hukum yang akan dibentuk. ${ }^{12}$ Di dalam tulisannya yang lain, Padmo Wahjono memperjelas definisi tesebut dengan mengatakan bahwa politik hukum adalah kebijakan penyelenggara negara tentang apa yang dijadikan kriteria untuk

\footnotetext{
${ }^{12}$ Padmo Wahjono, Indonesia Negara Berdasarkan Atas Hukum, Cet II, Ghalia Indonesia, Jakarta, 1986, hlm 160 Dalam Moh. Mahfud MD, Politik Hukum di Indonesia, Edisi Revisi, Cet VI, Rajawali Pers, Jakarta, 2014, hlm 1
}

menghukumkan sesuatu yang di dalamnya mencakup pembentukan, penerapan dan penegakan hukum. ${ }^{13}$ Dengan demikian, politik hukum menurut Padmo Wahjono berkaitan dengan hukum yang berlaku dimasa datang dan baru pada tahap cita-cita (Ius Constituendum). Hal ini berbeda dengan pendapat Teuku Mohammad Radhie yang mendefinisikan politik hukum sebagai suatu kehendak penguasa negara mengenai hukum yang berlaku diwilayahnya dan mengenai arah perkembangan hukum yang di bangun. ${ }^{14}$ Disini tampaknya definisi politik hukum memiliki dua wajah yang saling berkaitan dan berkelanjutan, yaitu ius constitutum dan ius constituendum.

Selain itu Sadjipto Rahardjo mengartikan politik hukum sebagai aktivitas memilih dan cara yang hendak dicapai untuk mencapai tujuan sosial dengan hukum tertentu di dalam

13 Padmo Wahjono, Menyelisik Proses Terbentuknya Peraturan Perundangundangan, majalah Forum Keadilan, No. 29, April 1991, Hlm. 65

14 Soedarto, Perkembangan Ilmu Hukum dan Politik Hukum, Dalam Jurnal Hukum dan Keadilan No. 3 Tahun ke VII, JanuariFebruari, 1998, hlm. 13. Dalam Ma'shum Ahmad, Politik Hukum Kekuasaan Kehakiman Pasca Amandemen Undang-Undang Dasar 1945, Total Media, Yogyakarta, 2009, Hlm. 27 
masyarakat yang cakupannya meliputi jawaban atas beberapa pertanyaan mendasar, yaitu 1) tujuan apa yang hendak dicapai melalui sistem yang ada?; 2) cara-cara apa dan yang mana yang dirasa paling baik untuk dipakai dalam mencapai tujuan tersebut; 3) kapan waktunya dan melalui cara bagaimana hukum itu perlu diubah; 4) dapatkah suatu pola yang baku dan mapan dirumuskan untuk membantu dalam memutuskan proses pemilihan tujuan serta cara-cara untuk mencapai tujuan tersebut dengan baik. ${ }^{15}$

Dari berbagai pemahaman tersebut, Mahfud MD menyimpulkan bahwa politik hukum adalah "legal policy" atau garis (kebijakan) resmi tentang hukum yang akan diberlakukan baik dengan pembuatan hukum baru maupun dengan penggantian hukum lama, dalam rangka mencapai tujuan negara. Dengan kata lain, politik hukum merupakan pilihan tentang hukum-hukum yang akan diberlakukan sekaligus pilihan tentang hukum-hukum yang akan di cabut atau tidak diberlakukan yang kesemuanya

15 Sadjipto Rahardjo, Imu Hukum Cet. III, Citra Aditya Bakti, Bandung, 1991, hlm. 352-353 dimaksudkan untuk mencapai tujuan negara seperti yang tercantum dalam pembukaan UUD NRI Tahun 1945. ${ }^{16}$ Dalam hal ini, terlihat jelas bahwa hukum diposisikan sebagai alat untuk mencapai tujuan negara.

Mengkaitkan pemahaman mengenai politik hukum tersebut dengan berbagai pengaturan tentang netralitas ASN dalam Pilkada serentak Tahun 2018, berikut penulis uraikan terlebih dahulu apa yang menjadi pokok-pokok dari masingmasing regulasi tersebut: pertama, Undang-Undang Nomor 5 Tahun 2014 tentang Aparatur Sipil Negara. Undangundang ini lahir dengan alasan salah satunya sebagai upaya untuk membangun ASN yang memiliki integritas, profesional, netral dan bebas dari intervensi politik, bersih dari praktik korupsi, kolusi, dan nepotisme serta mampu menyelenggarakan pelayanan publik bagi masyarakat dan mampu menjalankan peran sebagai unsur perekat persatuan dan kesatuan bangsa berasarkan Pancasila dan Undang-Undang Dasar Negara Republik Indonesia (UUD NRI)

\footnotetext{
${ }^{16}$ Moh. Mahfud MD, Politik Hukum di Indonesia..., Op.Cit, hlm. 1
} 
Tahun 1945 dalam rangka mewujudkan tujuan negara. ${ }^{17}$ Spesifik berbicara mengenai netralitas ASN didalam undang-undang tersebut, dapat dilihat bahwa asas netralitas menjadi 1 dari 13 asas penting dalam penyelenggaraan kebijakan dan manajemen ASN. Artinya, dalam upaya membentuk ASN sebagaimana dicita-citakan untuk mewujudkan tujuan negara, netralitas menjadi harga mati yang tidak dapat dikesampingkan.

Kedua, Undang-Undang Nomor 10 Tahun 2016 tentang Perubahan Kedua atas Undang-Undang Nomor 1 Tahun 2015 Tentang Penetapan Peraturan Pemerintah Pengganti Undang-Undang Nomor 1 Tahun 2014 Tentang Pemilihan Gubernur, Bupati, Dan Walikota Menjadi Undang-Undang. Pada prinsipnya undang-undang ini lahir dalam rangka menjamin pemilihan kepala daerah yang dilaksanakan secara demokratis sebagaimana amanat Pasal 18 ayat (4) UUD NRI Tahun 1945. Pemilihan yang demokratis tersebut dapat terwujud apabila kedaulatan rakyat dan demokrasi

17 Konsideran huruf a Undang-Undang Nomor 5 Tahun 2014 tentang Aparatur Sipil Negara. dari rakyat telah dijunjung tinggi sebagai syarat utama dalam sebuah pemilihan. ${ }^{18}$ Kaitannya dengan netralitas ASN, didalam Pasal 7 undang-undang tersebut telah disebutkan secara jelas bahwa apabila terdapat seorang PNS ingin mendaftarkan diri sebagai bakal calon kepala daerah, maka seorang tersebut harus terlebih dahulu mengundurkan diri sebagai PNS sejak mendaftarkan diri sebagai calon kepala daerah. ${ }^{19}$ Dari sini dapat kita lihat bahwa sebenarnya persoalan netralitas ANS yang dalam hal ini adalah PNS merupakan satu kesatuan dalam upaya mewujudkan pilkada yang demokratis.

Ketiga, Peraturan Pemerintah Nomor 53 Tahun 2010 tentang Disiplin Pegawai Negeri Sipil. Pada prinsipnya hadirnya PP ini ditujukan untuk mewujudkan PNS yang handal, profesional dan bermoral. Dalam rangka mewujudkan PNS sebagaimana dimaksud, PP ini kemudian memuat aturan yang diantaranya adalah kewajiban, larangan dan hukuman

\footnotetext{
18 Lihat Konsideran huruf a Undang-Undang Nomor 5 Tahun 2014 tentang Aparatur Sipil Negara.

${ }^{19}$ Lihat Pasal 7 huruf s Undang-Undang Nomor 5 Tahun 2014 tentang Aparatur Sipil Negara.
} 
disiplin yang dapat dijatuhkan kepada PNS yang telah terbuki melakukan pelanggaran. Berkenaan dengan kewajiban PNS yang berkaitan dengan netralitas ASN dalam pelaksanaan Pilkada, telah dikatakan dalam Pasal 3 bahwa PNS wajib menaati segala ketentuan peraturan perudang-undangan. Sementara larangan bagi PNS, dalam Pasal 4 telah ditegaskan pula bahwa PNS dilarang salah satunya untuk memberikan dukungan kepada calon Kepala Daerah/Wakil Kepala Daerah, dengan cara: terlibat dalam kegiatan kampanye untuk mendukung calon Kepala Daerah/Wakil Kepala Daerah; menggunakan fasilitas yang terkait dengan jabatan dalam kegiatan kampanye; membuat keputusan dan/atau tindakan yang menguntungkan atau merugikan salah satu pasangan calon selama masa kampanye; dan/atau mengadakan kegiatan yang mengarah kepada keberpihakan terhadap pasangan calon yang menjadi peserta pemilu sebelum, selama, dan sesudah masa kampanye meliputi pertemuan, ajakan, himbauan, seruan, atau pemberian barang kepada PNS dalam lingkungan unit kerjanya, anggota keluarga, dan masyarakat.

Keempat, Peraturan Pemerintah Nomor 42 Tahun 2004 tentang Pembinaan Jiwa Koprs dan Kode Etik Pegawai Negeri Sipil. Jika kita telisik didalam konsideran dapat diketahui bahwa PP Nomor 42 Tahun 2004 lahir sebagai langkah kongkrit untuk menanamkan rasa Kesatuan dan persatuan, kebersamaan, kerja sama, tanggung jawab, dedikasi, disiplin, kreativitas, kebanggaan dan rasa memiliki organisasi Pegawai Negeri Sipil dalam Negara Kesatuan Republik Indonesia (Jiwa Korps) kepada seluruh PNS serta mengamalkan etika bagi PNS. Kaitannya dengan netralitas ASN, Pasal 11 PP tersebut telah secara tegas menjelaskan bahwa salah satu ruang lingkup etika terhadap diri sendiri (PNS) adalah menghindari konflik kepentingan pribadi, kelompok, maupun golongan. Selain itu, di dalam PP tersebut juga dikatakan bahwa salah satu etika PNS dalam kehidupan bernegara yaitu menaati semua peraturan perundang-undangan yang berlaku dalam melaksanakan tugas. Artinya, ketika peraturan perundang- 
undangan telah menghendaki agar ASN menjunjung tinggi netralitas dalam Pilkada 2018, maka hal itu merupakan harga mati yang harus dilakukan sebagai bagian yang tidak terpisahkan dalam upaya membina jiwa Koprs ASN.

Kelima, Surat Edaran Komisi Aparatur Sipil Negara Nomor B.2900/KASN/11/2017 tertanggal 10 November 2017 tentang Pengawasan Netralitas Pegawai Aparatur Sipil Negara pada Pilkada Serentak 2018. Surat edaran ini merupakan bentuk kongkrit pelaksanaan tugas Komisi Aparatur Spil Negara (KASN) dalam menjaga netralitas ASN. Rujukan dalam pelaksanaan tugas tersebut mengacu pada Undang-Undang Nomor 5 Tahun 2014 tentang Aparatur Sipil Negara, PP Nomor 42 Tahun 2004 dan PP Nomor 53 Tahun 2010 sebagaimana telah penulis uraikan sebelumnya. Pada prinsipnya, surat edaran ini hadir sebagai bentuk upaya lanjutan dalam rangka mewujudkan ASN yang profesional, netral dan bebas dari intervensi politik.

Keenam, Surat Edaran Menteri Pendayagunaan Aparatur Sipil Negara dan Reformasi Birokrasi Nomor
B/71/M/SM.00.00/2017 tertanggal 27 Desember 2017 tentang Pelaksanaan Netralitas Aparatur Sipil Negara. Jika dicermai, pada prinsipnya surat edaran ini memiliki maksud yang sama dengan surat edaran yang dikeluarkan oleh KASN, yakni merupakan upaya lanjutan untuk mewujudkan ASN yang profesional, netral dan bebas dari intervensi politik. Di dalamnya, surat edaran ini berbicara mengenai seruan ataupun ajakan kepada para Pejabat Pembina Kepegawaian dan seluruh ASN agar memperhatikan beberapa regulasi berkenaan dengan netralitas ASN dalam penyelenggaraan Pilkada Serentak 2018, pemilihan legislatif tahun 2019 dan pemilihan presiden dan wakil presiden 2019. Selain itu surat edaran ini juga berbicara mengenai mekanisme pemantauan dan evaluasi terhadap hal tersebut.

Berdasarkan uraian dari berbagai regulasi yang mengatur mengenai netralitas ASN diatas, dapat kita lihat bahwa politik hukum pembentuk UU dan pemerintah yang memilih untuk membentuk berbagai regulasi tersebut adalah dalam rangka menjaga integritas, profesionalitas dan netralitas ASN demi 
terwujudnya Pilkada yang demokratis sebagaimana amanat Pasal 18 ayat (4) UUD UUD NRI 1945. Pembentuk UU dan pemerintah menyadari betul bahwa Pilkada yang demokratis tidak berdiri dengan sendirinya. Untuk dapat menjelma sebagai sebuah pemilihan yang demokratis, Pilkada membutuhkan pilarpilar yang harus menopangnya. Dalam konteks ini, integritas, profesionalitas dan netralitas ASN merupakan satu dari sekian pilar penting yang mutlak dibutuhkan untuk mewujudkan Pilkada yang demokratis.

Namun apapun politik hukum dari berbagai pengaturan mengenai netralitas ASN khususnya dalam pelaksanaan Pilkada Serentak Tahun 2018, tidak dapat dipungkiri bahwa netralitas ASN seperti satu persoalan yang tidak pernah terselesaikan. Pembentuk UU dan pemerintah telah membuat ragam pengaturan untuk membatasi hubungan ASN dengan kegiatan politik praktis guna memperkuat eksistensi dari netralitas. Namun apa boleh buat, setiap berlangsungnya pesta demokrasi seperti halnya Pilkada Serentak, selalu saja diwarnai oleh maraknya pemberitaan tentang pelanggaran netralitas oleh oknum ASN.

Dalam dua tahun terakhir saja (20172018), ribuan laporan dugaan pelanggraan netralitas ASN diterima oleh Badan Pengawas Pemilu (Pemilu). Pada Pilkada 2017, terdapat setidaknya 1.256 laporan dan 878 temuan pelanggaran netralitas ASN. Dari jumlah itu, 916 kasus masuk ranah pidana sedangkan 682 kasus masuk ranah pelanggaran administrasi. ${ }^{20}$ Sementara terhitung Maret 2018 setidaknya Bawaslu telah menerima 117 laporan megenai dugaan pelanggaran netralitas ASN yang terjadi baik di pusat, provinsi, maupun kabupaten/kota. Keseluruhan laporan tersebut telah diserahkan oleh Bawaslu kepada Kementrian Pendayagunaan Aparatur Negara dan Reformasi Birokrasi (KemenPAN-R). Asdep Pembinaan Integritas dan Penegakan Disiplin SDM Aparatur KemenPAN-RB menyatakan bahwa pelanggaran yang dilakukan antara lain melakukan ajakan memilih, menghadiri kegiatan politik, dan

\footnotetext{
${ }^{20}$ https://beritagar.id/artikel/editorial/mengharapka n-netralitas-asn-dalam-pilkada [diakses pada 19 Oktober 2018]
} 
memberikan sambutan pada acara silaturahmi bakal pasangan calon. Pelanggaran netralitas terbanyak berada di Provinsi Sulawesi Tenggara dengan 42 temuan pelanggaran, kemudian Sulawesi Selatan dengan 34 temuan pelanggaran. ${ }^{21}$ Lebih lanjut, dalam sumber yang lain tercatat bahwa terhitung bulan Mei 2018 setidaknya sebanyak 219 ASN diberhentikan sementara terkait pelangaran netralitas dalam Pilkada Tahun 2018. ${ }^{22}$

Setelah pelaksanaan Pilkada Tahun 2018, Bawaslu mencatat 3.567 laporan dugaan pelanggaran Pilkada, dari total tersebut, 721 kasus dugaan pelanggaran netralitas yang dilakukan oleh pegawai negeri sipil selama Pilkada 2018. ${ }^{23}$ Kurang lebih 500 pelanggaran netralitas ASN telah ditindak lanjuti oleh

\footnotetext{
${ }^{21}$ https://pilkada.jpnn.com/news/inilah-daerahdengan-pelanggaran-netralitas-asn-terbanyak [diakses pada 16 Juni 2018]

${ }^{22}$ https://tirto.id/219-asn-diberhentikan-sementaraterkait-netralitas-pilkada-2018-cJSC baca juga https://www.menpan.go.id/site/beritaterkini/pelanggaran-netralitas-asn-banyak-terjadidi-sulsel-dan-sultra [diakses pada 16 Juni 2018] ${ }^{23} \mathrm{http} / / / \mathrm{www}$. tribunnews.com/nasional/2018/07/23 /bawaslu-temukan-721-kasus-pelanggaran-asnselama-pilkada-2018 [diakses pada 19 Oktober 2018]
}

Bawaslu $^{24}$, adapun kasus yang paling banyak ditemukan adalah terkait netralitas ASN dalam bidang administrasi. ${ }^{25}$

Data dan fakta yang penulis uraikan diatas membuktikan kepada kita semua bahwa akar persoalan netralitas PNS sampai saat ini belum mampu terjawab secara baik dengan hadirnya berbagai pengaturan mengenai netralitas ASN. Selain itu, dapat diasumsikan pula bahwa pemerintah masih kesulitan menemukan formulasi yang tepat untuk menjawab perseoalan netralitas tersebut. Penulis kemudian bependapat bahwa hal ini terjadi oleh karena konsep netralitas masih dirasakan belum dengan sepenuh hati oleh seluruh pihak yang terlibat. Alhasil, hadirnya berbagai regulasi tersebut tak ayal menjadi suatu yang ada namun seolah-olah tidak ada. Bahasa arab menyebutnya dengan istilah wujuduhu ka adamihi.

\footnotetext{
https://news.detik.com/berita/4082355/bawaslutindak-500-pelanggaran-asn-di-pilkada-2018 [diakses pada 19 Oktober 2018]

${ }^{25} \mathrm{https}$ ://nasional.kompas.com/read/2018/06/25/18 180101/bawaslu-temukan-500-kasus-asn-taknetral-pada-pilkada-serentak [diakses 19 Oktober 2018)
} 


\section{B. Urgensi Netralitas Aparatur Sipil Negara dalam Pilkada Serentak 2018}

S.F. Marbun dan M. Mahfud MD menyatakan bahwa salah satu persoalan besar bangsa dalam kehidupan bernegara adalah persoalan netralitas pegawai negeri. Hal ini dikarenakan secara teoritis sulit ditemukan landasan yang dapat memberikan alasan pembenar bagi dimungkinkannya pegawai negeri untuk terlibat dalam kegiatan-kegiatan politik praktis. $^{26}$

Secara historikal, persoalan netralitas ASN yang ketika itu dimaknai sebagai netralitas birokrasi ${ }^{27}$ muncul sejak pemilihan umum (pemilu) pertama tahun 1955. Diketahui bahwa pasca pemilu 1955, partai politik pemenang pemilu silih berganti dalam memimpin dan mengendalikan pemerintahan yang parlementer. Sehingganya, netralitas

26 Sri Hartini, Penegakan Netralitas Pegawai Negeri Sipil, Jurnal Dinamika Hukum, Vol. 9 No. 3, September, 2009, hlm. 263.

${ }^{27}$ Netralitas birokrasi merupakan sebuah sistem dimana birokrasi tidak akan berubah dalam melakukan menjaga pelayannya kepada public/masyarakat, walaupun pimpinannya berganti dengan pimpinan yang lain, dalam Policy Brief yang disusun oleh Bidang Pengkajian Sistem, Komisi Aparatur Sipil Negara, Tahun 2017. birokrasi pemerintah mulai terganggu oleh pengaruh partai politik. Pengaruh tersebut kemudian berlanjut pada saat sistem pemerintahan berganti menjadi sistem pemerintahan presidensial, rezim orde baru, reformasi hingga saat ini. ${ }^{28}$

Atas persoalan tersebut, negara kemudian membuat pengaturan tentang pembatasan akivitas ASN melalui asas netralitas yang diinternalisasikan dalam Pasal 2 huruf f UU ASN dan berbagai regulasi lainnya yang telah penulis uraikan pada pembahasan sebelumnya. Telah diketahui pula bahwa pengaturan terhadap netralitas ASN dimaksudkan untuk menjaga integritas, profesionalitas dan netralitas ASN demi terwujudnya Pilkada yang demokratis sebagaimana amanat Pasal 18 ayat (4) UUD NRI 1945.

Dalam perspektif yang lain, konsepsi tentang pembatasan peran serta ASN dimaksudkan untuk menciptakan aparat yang bersih dalam upaya menciptakan good governance. Good governance berorientasi pada Pertama, orientasi ideal, negara yang diarahkan pada

\footnotetext{
${ }^{28}$ Miftah Thoha. Birokrasi dan Politik di Indonesia, PT Raja Grafindo Persada, Jakarta, 2005.
} 
pencapaian tujuan nasional. Orientasi ini bertitik tolak pada demokratisasi dalam kehidupan bernegara. Adapun orientasi kedua adalah sejauhmana pemerintah mempunyai kompetensi dan sejauhmana struktur serta mekanisme politik serta administratif berfungsi secara efektif dan efisien. Dalam kaitannya dengan netralitas PNS, maka good governance dapat terealisir jika memiliki aparatur pemerintah yang tidak memihak dan profesional. Pandangan ini sesuai dengan kedudukan manusia, seperti ungkapan "not the man but the man behind the gun". 29

Dalam konteks netralitas ASN pada pelaksanaan Pilkada Serentak ahun 2018, dapat diketengahkan bahwa selain untuk menjaga integritas, profesionalitas dan netralitas ASN demi terwujudnya Pilkada yang demokratis sebagaimana amanat Pasal 18 ayat (4) UUD UUD NRI 1945, netralitas ASN sebenarnya menjadi penting diwujudkan untuk memperoleh kepastian, kemanfaatan dan keadilan hukum guna membatasi kekuasaan terhadap kemungkinan bergeraknya

${ }^{29}$ Sri Hartini, dkk..., Op.Cit, hlm 258. kekuasaan atas nalurinya sendiri, yang pada akhirnya mengarah pada penyalahgunaan kekuasaan (abuse of power). Dengan kata lain, netralitas ASN menjadi penting untuk diwujudkan guna mencegah penyalahgunaan wewenang (abuse of power) baik oleh ASN maupun oleh calon yang bersangkutan. Ketika ASN maupun calon yang bersangkutan terbebas dari kemungkinan-kemungkinan penyalahgunaan wewenang, niscaya good governance akan terwujudkan.

Terlebih jika kita melihat pegawai ASN berkedudukan sebagai unsur dari aparatur negara, bukan sebagai unsur aparatur pemerintahan. Sebagai konsekuensi dari hal tersebut, maka loyalitas ASN harus dituju dan berpuncak kepada negara yang sifatnya tetap, bukan kepada pemerintahan yang sifatnya sementara dan akan berganti. ${ }^{30}$

Bagaimanapun, konsep netralitas adalah memberikan pembatasan dan kepastian akan peran dari PNS (baca ASN) dalam pemerintahan. Implikasi pembatasan adalah penegakan hukum

\footnotetext{
${ }^{30}$ Stevenril Mokoagow, Pelanggaran Netralitas Aparatur Sipil Negara dalam Pemioihan Umum Kepala Daerah, Lex Administratum, Vol. 4 No. 4, April 2016, hlm 6.
} 
yang beorientasi pada jaminan PNS (baca ASN) dalam melaksanakan tugas secara profesional. Konsep pembatasan ini memiliki korelasi dengan konsep Islam sebagaimana disampaikan oleh Ibnu Timiyah bahwa "Semua kewenangan dalam Islam tujuannya hanyalah amar maruf nahi munkar". 31

\section{KESIMPULAN}

Dari hasil pembahasan yang telah penulis uraikan diatas, dapat disimpulkan dua hal sebagai berikut:

a) Politik hukum pembentuk UU dan pemerintah yang memilih untuk membentuk berbagai regulasi tersebut adalah dalam rangka menjaga integritas, profesionalitas dan netralitas ASN demi terwujudnya Pilkada yang demokratis sebagaimana amanat Pasal 18 ayat (4) UUD UUD NRI 1945. Pembentuk UU dan pemerintah menyadari betul bahwa Pilkada yang demokratis tidak berdiri dengan sendirinya. Untuk dapat menjelma sebagai sebuah pemilihan yang demokratis, Pilkada membutuhkan

31 Ni'matul Huda, Problematika Pembatalan Peraturan Daerah, Yogyakarta, FH UII Press, 2010, hlm. 47-48 pilar-pilar yang harus menopangnya.

Dalam konteks ini, integritas, profesionalitas dan netralitas ASN merupakan satu dari sekian pilar penting yang mutlak dibutuhkan untuk mewujudkan Pilkada yang demokratis.

b) Netralitas ASN menjadi penting untuk diwujudkan guna mencegah penyalahgunaan wewenang (abuse of power) baik oleh ASN maupun oleh calon yang bersangkutan.

\section{SARAN}

Telah diketahui bersama bahwa netralitas ASN masih menjadi persoalan yang belum terselesaikan hingga saat ini. Guna mengatasi hal tersebut, instrumen hukum yang baik tidaklah cukup tanpa didukung dengan budaya hukum yang baik. Oleh karena itu, penulis menyarankan kepada seluruh pihak khususnya kepada ASN untuk bersamasama membangun budaya hukum yang baik dengan menjunjung tinggi nilai-nilai netralitas ASN dalam pelakanaan Pemilihan Kepala Daerah Serentak Tahun 2018. Selain itu, disarankan pula kepada seluruh masyarakat untuk terlibat aktif dalam melakukan pengawasan terhadap netralitas ASN sebagaimana dimaksud. 
DAFTAR PUSTAKA

\section{A. Buku}

Ma'shum Ahmad, Politik Hukum

Kekuasaan Kehakiman

Pasca Amandemen Undang-

Undang Dasar 1945, Total

Media, Yogyakarta, 2009.

Miftah Thoha. Birokrasi dan Politik

di Indonesia, PT Raja

Grafindo Persada, Jakarta, 2005.

Moh. Mahfud MD, Politik Hukum di Indonesia, Edisi Revisi, Cet VI, Rajawali Pers, Jakarta, 2014.

Ni'matul Huda, Problematika Pembatalan Peraturan

Daerah, Yogyakarta, FH

UII Press, 2010

Padmo Wahjono, Menyelisik Proses Terbentuknya Peraturan Perundang-undangan, majalah Forum Keadilan, No. 29, April 1991.
Sadjipto Rahardjo, Imu Hukum Cet. III, Citra Aditya Bakti, Bandung, 1991.

Sri Hartini, Hukum Kepegawaian Di Indonesia, Sinar Grafika, Jakarta, 2008.

Sri Hartini, Penegakan Netralitas Pegawai Negeri Sipil, Jurnal Dinamika Hukum, Vol. 9 No. 3, September, 2009.

Stevenril Mokoagow, Pelanggaran Netralitas Aparatur Sipil Negara dalam Pemioihan Umum Kepala Daerah, Lex Administratum, Vol. 4 No. 4, April 2016.

Tedi Sudajat dan Agus Mulya Karsona, Menyoal Makna Netralitas Pegawai Negeri Sipil dalam Undang-Undang Nomor 5 Tahun 2014 tentang Aparatur Sipil Negara, Jurnal Media Hukum, Vol.23, No.1, Juni 2016. 


\section{B. Peraturan Perundang-Undangan}

Undang-Undang Nomor 10 Tahun

2016 tentang Perubahan

Kedua atas Undang-Undang

Nomor 1 Tahun 2015

Tentang Penetapan

Peraturan Pemerintah

Pengganti Undang-Undang

Nomor 1 Tahun 2014

Tentang Pemilihan

Gubernur, Bupati, Dan

Walikota Menjadi Undang-

Undang

Peraturan Pemerintah Nomor 53

Tahun 2010 tentang Disiplin

Pegawai Negeri Sipil

Peraturan Pemerintah Nomor 42 Tahun 2004 tentang Pembinaan Jiwa Koprs dan

Kode Etik Pegawai Negeri Sipil

Surat Edaran Komisi Aparatur Sipil Negara Nomor

B.2900/KASN/11/2017

Surat Edaran Menteri Pendayagunaan Aparatur Sipil Negara dan
Reformasi Birokrasi Nomor

B/71/M/SM.00.00/2017

\section{Sumber Lainnya}

http://repository.umy.ac.id/bitstream/

handle/123456789/16915/6.

$\% 20 \mathrm{BAB} \% 20 \mathrm{II}$.pdf?sequen

ce $=6 \&$ is Allowed $=y$ [diakses

pada 16 Oktober 2018]

http://www.tribunnews.com/nasional/

2018/07/23/bawaslu-

temukan-721-kasus-

pelanggaran-asn-selama-

pilkada-2018 [diakses pada

19 Oktober 2018]

https://beritagar.id/artikel/editorial/m

engharapkan-netralitas-asn-

dalam-pilkada [diakses pada

19 Oktober 2018]

https://kbbi.web.id/netralitas [diakses

pada 16 Oktober 2018]

https://nasional.kompas.com/read/20

18/06/25/18180101/bawaslu

-temukan-500-kasus-asn-

tak-netral-pada-pilkada-

serentak [diakses 19

Oktober 2018)

https://news.detik.com/berita/408235

5/bawaslu-tindak-500- 


$$
\begin{aligned}
& \text { pelanggaran-asn-di-pilkada- } \\
& 2018 \text { [diakses pada } 19 \\
& \text { Oktober 2018] } \\
& \text { https://pilkada.jpnn.com/news/inilah- } \\
& \text { daerah-dengan-pelanggaran- } \\
& \text { netralitas-asn-terbanyak } \\
& \text { [diakses pada 19 Oktober } \\
& \text { 2018] } \\
& \text { https://tirto.id/219-asn-diberhentikan- } \\
& \text { sementara-terkait-netralitas- } \\
& \text { pilkada-2018-cJSC baca } \\
& \text { juga } \\
& \text { https://www.menpan.go.id/si } \\
& \text { te/berita- } \\
& \text { terkini/pelanggaran- } \\
& \text { netralitas-asn-banyak- } \\
& \text { terjadi-di-sulsel-dan-sultra } \\
& \text { [diakses pada 19 Oktober } \\
& \text { 2018] }
\end{aligned}
$$

